\title{
Financial Instruments In Italian Co-operative Companies
}

\author{
Sara Meloni
}

April 2013

\begin{abstract}
Art. 2511 of the Italian Civil Code defines co-operatives as companies "with variable capital and mutual purpose". Therefore main characteristics of cooperative companies are: capital variability and most of all the pursuit of a mutual purpose. The cooperative company, while pursuing a mutual purpose, carries out in any case a business activity. Lawmakers has intervened at various times on the financial structure of cooperative companies, providing access to increasingly articulated funding sources. A turning point in this regard has been represented by Law n. 59 of 1992, which provided two special classes of shares reserved for cooperatives: investment shares and voting capital shares in the co-operatives. Both categories are addressed to special subjects, even without the requirements identified by the statute for the admission to the company, not interested in the pursuit of the mutual purpose but to the return on capital invested. Investment shares are freely transferable and may have a preferential treatment with regard to the distribution of profits that can go so far as to the identification of an interest rate increased by two percent compared to that for the cooperative members; voting capital shares in the co-operatives however, are similar to savings shares, as they do not entitle to vote and have special capital franchisees as regards the distribution of profits and repayment of capital. Paragraph 1 of Article 2526 of the ICC allows the statute of co-operative companies "to provide for the issue of financial instruments in accordance with the regulation on limited shareholder companies". Therefore the question arises: what kind of financial instruments are governed under this law and if the reference is to the participatory financial instruments introduced by Legislative Decree no. $6 / 2003$ on public limited companies?
\end{abstract}

JEL Classification: G23, G34, P13

Key words: Co-operative, investment shares, nonvoting cooperative preferred shares, participating financial instruments.

Sara Meloni

Teaching Assistant in Business Law

Department of Law - LUISS Guido Carli

Research Fellow of Bruno Visentini Foundation

Mail: smeloni@luiss.it 


\section{Financial Instruments in Italian Co-operative Companies}

\section{Summary: 1. The co-operative company: main characteristics - 2. Financial structure - 3. Participatory financial instruments.}

1. Art. 2511 of the Italian Civil Code (hereinafter "ICC") defines cooperatives as companies "with variable capital and mutual purpose". Therefore main characteristics of co-operative companies are: capital variability and most of all the pursuit of a mutual purpose.

The mutual purpose means the activity of the company is aimed not to get the most return on capital invested by members, but to offer to members themselves goods and services in consumer co-operatives, or job opportunities in production and work co-operatives, on terms more favorable than those of the market. Thus, the real advantage for the co-operative members consists of either a saving of expenditure or an increase in pay, both made by eliminating intermediaries between "co-operative producer" and "consumer-members."

In general, co-operatives offer to members goods and services or employment opportunities at market prices and periodically pay sums of money out (so called repayments), corresponding to the difference between the current price and the price calculated according the relationship of mutuality between members and company.

With regard to the variability of the share capital, article 2524 of the ICC paragraphs 1 and 2 says "share capital is not determined in a specified amount. In co-operative companies the admission of new members as provided by article 2528, does not entail amendment to the statute of the company". Paragraph 1 of article 2527 of the ICC at this regards says "statute set out the requirements for the admission of new members and the procedure, according non-discriminatory criteria consistent with the mutual purpose and the economic activity". All subjects in possession of the una tantum identified requirements can apply to become member of the company: that is the so called "open door" principle. Co-operative companies are in any case public limited companies and, pursuant to art. 2519 c.c., are subject to the rules provided for public limited companies or, in existence of the conditions required by the Italian Civil Code, to the rules provided for limited liability companies.

The reform of company law has drawn a distinction between mainly mutual co-operatives and not mainly mutual co-operatives. 
Between the two types of co-operative companies there are, in fact, all things considered negligible differences for what concerns the organization structure, but relevant are the differences with reference to the tax benefits which are addressed only to mainly mutual co-operatives.

The pursuit of mutual purpose - common to both types of cooperatives justifies a number of provisions, partially divergent and stiffer for mainly mutual cooperatives regarding the distribution of dividends and repayments and distribution of reserves to members.

The mutual purpose is also the basis of certain rules regarding the organization of the company. Article 2542, paragraph 2, of the Italian Civil Code provides, for example, for the purpose of raising the degree of democracy in the context of company bodies, that "the majority of the directors shall be chosen among the co-operative members or from those indicated by the co-operative members as legal persons."

From an organizational point of view characteristic of cooperative companies is the vote pro-capite that markedly differs them from for profit companies, the second paragraph of Article 2538 of the ICC states that "each co-operative member has one vote, regardless of the value of the share or the number of shares held."

Thus, despite the general reference made by Article 2519 of the ICC (except compatibility filter) to the rules operating in the field of Plc or Ltd, it is evident that the mutual purpose of the activity carried out by cooperative companies affects their juridical discipline differentiating it considerably from that of the for profit Plc and Ltd.

2. The cooperative company, while pursuing a mutual purpose, carries out in any case a business activity. Co-operatives must therefore be able to carry out their business activities in the market in competition with for profit companies, in respect of which, especially in the past they were less competitive due to the lack of available funding channels.

Lawmakers has intervened at various times on the financial structure of cooperative companies, providing access to increasingly articulated funding sources. A turning point in this regard has been represented by Law n. 59 of 1992, which provided two special classes of shares reserved for cooperatives: investment shares and nonvoting cooperative preferred shares. Both categories are addressed to special subjects, even without the requirements identified by the statute for the admission to the company, not interested in the pursuit of the mutual purpose but to the return on capital invested. 
Investment shares are freely transferable and may have a preferential treatment with regard to the distribution of profits that can go so far as to the identification of an interest rate increased by two percent compared to that for the cooperative members; on the other hand, the investor members have a limitation in their decision-making power linked to the exercise of assembly voting rights.

Nonvoting cooperative preferred shares however, are similar to savings shares, as they do not entitle to vote and have special capital franchisees as regards the distribution of profits and repayment of capital.

thermore, Law n. 448 of 1998 provided the possibility for cooperatives to issue bonds, optionally convertible.

The reform of company law has further expanded the funding channels for co-operatives. Paragraph 1 of Article 2526 of the ICC allows the statute of co-operative companies "to provide for the issue of financial instruments in accordance with the regulation on limited shareholder companies" stating that it will always be on the statute to define "financial and administrative rights of financial instruments holders and the eventual conditions governing their transfer".

May, however, grant the right to vote on matters specifically identified and the right to appoint an independent director or a member of the supervisory body. In summary they are financial instruments suitable to pursue articulated economic functions and can take many different shapes, participating to a greater or lesser extent to the business risk. However they do not give the member status and, unlike actions, are not attributable to capital.

In order to identify the type of financial instruments that article 2526 of the ICC allow co-operative companies to issue is necessary to examine some further laws.

Article 2525 of the ICC paragraph 4 provides that the maximum limits set by the value of the share capital of each member does not apply, as well as with reference to other specific cases provided for by law, "for subscribers of financial instruments with administrative rights".

If, however, in these financial instruments are encompassed only participatory financial instruments, as provided by the last paragraph of article 2346 ICC, there would have been no need to specify the applicability of the limit of one hundred thousand euro (or eventually the highest for companies with more than five hundred members) since participatory financial instruments are not fractions of company capital.

Paragraph 3 of article 2526 of the ICC provides that "the withdrawal of 
financial instruments holders that have voting rights is governed by articles 2437 and following articles" and then by the dictated provisions governing the withdrawal of shareholders that do not lend themselves to be applied to the withdrawal of a non-member subject.

Even concerning the above provisions, the doctrine considers that financial instruments referred to art. 2526 of the ICC are not exactly coincident with those predicted from the last paragraph of art. 2346 of the Italian Civil Code.

Article 2526 ICC, therefore, providing that co-operatives can proceed to '"issue financial instruments in accordance with the rules applicable to the S.p.a ( Public Limited Company)", would allow the use of all funding channels provided for the S.p.a referring to a broad and extra-code concept of financial instrument suitable to cover also stocks and bonds. Therefore co-operative companies statute could provide the issue of real participatory financial instruments and various classes of shares.

In this context, however, cooperatives would have so many and different classes of shares not to justify the use, characterized by a more tight discipline, of investment shares and nonvoting cooperative preferred shares.

In any case it is not possible not to observe that rules on co-operative financial instruments are ambiguous and even more it is article 2526 ICC, named "co-operative members and financial partners,". Agreeing with the strict interpretation, which considers the reference contained in article 2526 of the Italian Civil Code limited only to participatory instruments, it must be concluded that the holders are absolutely no members, and the record of the article improperly uses the term "financial partners"; accepting, however, the second and broader interpretation, we must recognize that under the category of financial partners are included both real and proper shareholders and bondholders as also holders of participatory instruments.

3. Regardless of the scale, of greater or lesser extent, which is believed to be paid to the first paragraph of art. 2526 of the ICC one thing is certain: a co-operative company may issue participatory instruments.

Co-operatives participatory financial instruments, however, are not perfectly coincident with those issuable by for profit shareholders companies, in other words we do not face a straightforward transposition of the institute from one case to another. The statute autonomy meets specific limits that have their origins in the peculiarities of the cooperative company and, in particular, in the pursuit of mutual purpose.

First of all, in terms of administrative rights, there is a sort of "constraint of minority" at the expense of holders of financial instruments and, in gen- 
eral, at the expense of people other than the cooperative members so that they, not being interested in mutual exchanges, not assume a dominant position in decision-making processes of the company. In particular, the second part of paragraph 2 of article 2526 of the ICC states that "to holders of financial instruments cannot, however, be attributed more than one-third of the voting rights for all members present or represented at each general meeting."

As, however, regards the power to appoint members of the board of directors, who in any case must be in majority co-operative members, paragraph 4 of article 2542 of the ICC states that "the statute may provide that one or more directors are to be chosen from the different categories of shareholders, in proportion to the interest that each category has in social activity. In any case, to holders of financial instruments cannot be given the right to elect more than one third of the directors. "

Article 2544 of the ICC regards, then, of the supervisory body and its third paragraph provides that "the holders of financial instruments with administrative rights of directors can elect, if the statute provides so, a third of the members of the supervisory body ". Paragraphs 2 and 3 of art. 2344 of the ICC focus on better specifying the real limit to the power of appointment attributable to holders of financial instruments in case that the company has chosen, respectively, the dualistic and monistic governance and control system. In the first case, "holders of financial instruments cannot elect more than one third of the members of the supervisory board and more than a third of the members of the board of management".

According, however, to the provisions of paragraph 3 of article 2344 of the ICC "If the co-operative has adopted the system of administration under article 2409 sexiesdecies the directors elected by the holders of financial instruments to an extent not exceeding one third, cannot be attributed to operational powers or they may not be part of the executive committee".

In case the company has decided to adopt the monistic system of management and control, therefore, the members of the board of directors elected by the holders of the securities must be in possession of the independence requirements established for statutory auditors, or those further established in codes of conduct drawn up by trade associations or investment management companies of regulated markets, as may not hold positions of active administration and, probably, will be destined to be part of the committee of management control.

An analysis of the rules for the participation of holders of financial instruments in decision-making processes within the company shows that the lawmakers intended to give co-operative members a dominant position, so as not to allow persons not involved in the pursuit of mutual purpose to take over the management of the company. However regarding property rights, limits imposed by statutory autonomy find their origins in the need not to "force" too 
much characteristics of a company that still has not a for profit purpose.

The position of the holders of financial instruments, however, is very far from that of the co-operative members for what concerns the preferential rights attributable to them: only co-operative members are subject to the maximum percentage of distribution of dividends, prescribed by law for mainly mutual cooperatives or by statute for other type of co-operatives, and, once again, only to co-operative members can be applied the prohibition of the distribution of profits in the presence of a value between shareholders equity and total debt of the company exceeding one quarter.

Statute, however, cannot, in accordance with paragraph 2 of article 2526 ICC, provide for holders of financial instruments privileges in the distribution of profits and capital repayment going to affect the indivisible reserves in accordance with article 2545 ter of the ICC. Also they cannot be the subject of distribution profits to be allocated, according the annual rate determined by law, in mutual funds for the promotion and development of co-operation.

A characteristic of participatory co-operatives instruments that seems to arise from the text of article 2526 of the ICC and that further differentiates them from those provided in general for S.p.a ( public limited companies) regards the profile of their transfer. The financial instruments mentioned in the last paragraph of article 2346, indeed, can be transferred only in the presence of a statutory provision that in a way determines also the rules of their transfer; article 2526 of the ICC, however, states the statute requires co-operatives to define, during the identification of the characteristics of financial instruments, " the eventual conditions governing their transfer," almost as if, in the absence of other statutory provisions, these instruments were necessarily transferable.

The Italian Civil Code does not preclude co-operative members may be, at the same time, even subscribers of financial instruments. However, lawmakers were concerned about the opportunity to define clear limits to the rights attributable to holders of financial instruments that are already co-operative members. These additional limits imposed to the statute autonomy which find their raison in the peculiar subjective characteristic of the subscriber, reflect the need to preserve the characteristics of the mutual relationship existing between co-operative members and company.

Paragraph 3 letter to article 2545 of the ICC quinques enables the statute to allow the general meeting to assign to the members the divisible reserves through "the issue of financial instruments as prescribed in article 2526 of the ICC ", while paragraph 4 of the same article provides that "divisible reserves, due to the shareholder in the event of dissolution of the relationship, can be assigned, if the statute doesn't provide otherwise, through the issue of freely transferable financial instruments and they must be so when where the value between the net worth and the total debt of the company is less than one quar- 
ter. Similarly with regard to rebates the last paragraph of article 2545 sexies of the ICC provides that "the Assembly may approve the distribution of rebates to each member even through the proportional increase of their shares or the issue of new shares, notwithstanding the provisions of article 2525, or through the issue of financial instruments ".

Paragraph 2 of art. 2538 of the ICC further provides that "each co-operative member has one vote regardless of the value of the share or the number of shares held. Statute determines the limitations on voting rights of financial instruments offered for subscription to co-operative members. The ratio of this rule can be found in the need not to create interferences between the institution of one head-one vote and the right to vote eventually connected to financial instruments subscribed by co-operative members, in order not to endanger the balance of decision-making processes of co-operative companies.

Concerning instead property rights paragraph 1, letter b article 2514 of the ICC states only for the mainly mutual cooperatives, "the prohibition on remunerating financial instruments offered for subscription to the cooperative members in an amount more than two points superior from the maximum provided for dividends." Thus it is possible to ensure co-operative members through the subscription of financial instruments circumventing the limits on dividend distributions, motivated by intent speculative in nature rather than against the interest of mutual exchanges. 


\section{REFERENCES}

ANGELICI, C., La riforma delle società di capitali. Lezioni di diritto commerciale, Padova, Cedam, 2003

ASSOCIAZIONE PREITE, Il nuovo diritto delle società, Bologna, Il Mulino, 2003

BARTALENA, A., Le nuove tipologie di strumenti finanziari, in Banca, borsa e titoli di credito, I, Padova, Giuffrè, 2004

BASSI, A., Le società cooperative, in La riforma del diritto societario. Commento ai d.lgs. N. 5-6 del 17 gennaio 2003, Buonocore, V., (a cura di), Torino, Giappichelli, 2003

BIANCHI, L. A. , Prime osservazioni in tema di capitale e patrimonio nelle società per azioni, in Il nuovo diritto societario tra società aperte e società private, a cura di BENAZZO,P., PATRIARCA, S., PRESTI, G., (a cura di), Milano, Giuffrè, 2003

BORGIA CAVAllo, R., Della società per azioni, Tomo IV, delle obbligazioni, in Commentario al codice civile, Scialoja-Branca, (a cura di) GALGANO, F., Bologna, Zanichelli, 2005

CAMPOBASSO, G.,F., La riforma delle società di capitali e delle cooperative Torino, Utet, 2003

CAPO, G., Fenomenologia cooperativa e processi decisionalià in Giurisprudenza commerciale. Numero speciale: contributi alla riforma delle società di capitali, Supplemento al n. III, Milano, Giuffrè, 2004

CIAN, M., Strumenti finanziari e poteri di voice Milano, Giuffrè, 2006

CORSI, F., La nuova s.p.a: gli strumenti finanziari in Giurisprudenza Commerciale, Milano, Giuffrè, 2004

COSTI, R., I profili patrimoniali del nuovo diritto della cooperazione in Il nuovo diritto societario fra società aperte e società private, BENAZZO, P., PATRIARCA, S., PRESTI, G., (a cura di), Milano, Giuffrè, 2003

CUSA, E., Strumenti finanziari e soci finanziatori nelle cooperative in Rivista della cooperazione, Istituto Italiano di Studi Cooperativi "Luigi Luzzatti", Roma, II, 2003

DE ACUTIS, M., Il finanziamento dell'impresa societaria: I principali tratti caratterizzanti e gli altri strumenti finanziari partecipativi, in Le grandi 
opzioni della riforma del diritto e del processo societario, CIAN,G.,(a cura di), Padova, Cedam, 2004

ENRIQUES, L., Quartum non datur: appunti in tema di strumenti finanziari partecipativi in Inghilterra, negli Stati Uniti e in Italia, in Banca borsa e titoli di credito, I, Padova, Giuffrè, 2005

FERRI JR, G.,Fattispecie societaria e strumenti finanziari,in Profili patrimoniali e finanziari della riforma, Milano, 2004

GAlgano, F., Diritto commerciale. Edizione compatta. L'imprenditore - Le società, Bologna, Zanichelli, 2003

GENCO, R., La struttura finanziaria, in La riforma delle società cooperative, Milano, Ipsoa, 2003

LAMANDINI, M., Autonomia negoziale e vincoli di sistema nella emissione di strumenti finanziari da parte delle società per azioni e delle cooperative per azioni in Banca borsa e titoli di credito, I, Padova, Giuffrè, 2003

LAMANDINI, M., La riforma della struttura finanziaria delle cooperative: azioni e ibridi verso la quotazione, Intervento al Convegno su Gli statuti delle cooperative dopo la riforma del diritto societario, Bologna, 7 febbraio 2003, reperibile sul sito www.associazionepreite.it

MAGLIULO, F., Le categorie di azioni e strumenti finanziari nella nuova s.p.a., , Milano, Ipsoa, 2004

NONE, G., Commenti Art. 2346, comma VI, Art. 2349, comma II, Art. 2351, comma $V$, in Il nuovo diritto societario, Commento al d.lgs. 17 gennaio 2003, n. 6, d.lgs. 17 gennaio 2033 n. 5, d.lgs. 11 aprile 2002, n.61 (art. 1), Artt. 2325- 2409 c.c., in COTTINO, G., (diretto da), Bologna, Zanichelli

MIOLA, M., Gli strumenti finanziari partecipativi emessi a fronte di apporti, in I beni in natura conferibili, Trattato delle società per azioni, COLOMBO, G. E., PORTALE, G., (diretto da), 1***, Torino, Utet, 2004

MOntagnani, C., Commenti agli artt. 2370 e 2374 c.c. , in Società di capitali. Commentario, I, artt. 2325-2379 ter c.c. , NICCOLINI, G., STAGNO D' ALCONTRES, A., (a cura di), Jovene editore, 2004

MOSCO, G. D., Commento all'art. 2380 bis c.c., in Società di capitali. Commentario, II, artt. 2380-2448 c.c., NICCOLINI, G., STAGNO D'ALCONTRES, A., (a cura di), Jovene editore, 2004 
NOTARI, M., Le categorie speciali di azioni e gli strumenti finanziari partecipativi, in AA.VV, Il nuovo ordinamento delle società Ipsoa, Milano, 2003

NOTARI, M., Azioni e strumenti finanziari: confini delle fattispecie e profili di disciplina in Banca Borsa e Titoli di Credito, Padova, Giuffrè, 2003

NOTARI, M., Problemi aperti in tema di struttura finanziaria della s.p.a., Intervento alla Tavola rotonda le società e il nuovo diritto al termine del periodo transitorio, Milano, 20 settembre 2004, in Le società, I, Milano, Ipsoa, 2005

PISANI MASSAMORMILE, A., Azioni ed altri strumenti finanziari partecipativi in Rivista delle Società, II, Milano, Giuffrè, 2003

PRESTI, G.,Cooperative e modellismo giuridico, Intervento al Convegno su Gli statuti delle imprese cooperative dopo la riforma del diritto societario, Bologna, 7 febbraio 2003reperibile sul sito www.associazionepreite.it

SALAFIA, V.Il conferimento di opere e servizi secondo la riforma societaria in Le Società, XII, 2003

STAGNO D'ALCONTRES, A.,Commenti agli artt. 2346, 2349, 2351 e 2376 c.c. , in Società di capitali. Commentario, I, artt. 2325-2379 ter c.c., NICCOLINI, G., STAGNO D'ALCONTRES, A., (a cura di), Jovene editore, 2004

RACUGNO, G.,I nuovi strumenti finanziari delle società cooperative in Banca, borsa e titoli di credito, V, Padova, Giuffrè, 2004

TOMBARI, U., La nuova struttura finanziaria della società per azioni (Corporate Governance e categorie rappresentative del fenomeno societario), in Rivista delle società, V, Milano, Giuffrè, 2004

TOMBARI, U.,Nuovi strumenti di finanziamento nella s.p.a.: gli strumenti finanziari non partecipativi e partecipativi dotati di diversi diritti patrimoniali ed amministrativi (art. 4, sesto comma, lettera c), reperibile sul sito internet www.associazionepreite.it 